\title{
THE BLACK SEA REGION IN THE SOVIET HISTORY TEXTBOOKS: FEATURES OF INTERPRETATION
}

\author{
Roman Kazankov \\ V. N. Karazin Kharkiv National University \\ romankazankov@karazin.ua, https://orcid.org/0000-0003-4593-1493 \\ Stanislav Ivanov \\ Kharkiv National University of Internal Affairs \\ stanislavivanov713@gmail.com, https://orcid.org/0000-0003-0166-9016
}

Мета. Дослідити процес формування та характерні риси образу чорноморського регіону в радянських шкільних підручниках з історії.

Методи. Основним інструментом дослідження був контент-аналіз змісту радянських шкільних підручників з історії (для початкової та середньої школи).

Результати. В контексті часткової зміни базисних положень радянської історіографії у післявоєнний період та становлення нової наднаціональної спільноти «радянського народу» особливого значення набувало вивчення поліетнічних регіонів, де відбувалася взаємодія представників етнічних спільнот Радянського Союзу. В иьому контексті актуалізується осмислення/переосмислення чорноморської проблематики. Комплексний аналіз радянських шкільних підручників з історії надасть можливість сформувати уявлення щуодо підходів до інтерпретації чорноморського регіону.

Радянські шкільні підручники з історії вивчалися у великій кількості наукових досліджень. Втім, проблематика чорноморського регіону $і$ досі залишається недостатньо опрацьованою. Використовуючи зміст радянських икільних підручників з історії, дослідники висвітлювали найрізноманітніші аспекти - проблематику історичної пам'яті, важливі подіі (війни, революиіï), формування ідентичності (Klymenko L., Janmaat J., Gaworek N. та ін.). Окремі дотичні до чорноморської проблематики аспекти містяться у наукових прачях, які досліджували прочес створення радянських підручників (Телегуз I.), вивчали важливість икільних підручників у історичних та історіографічних прачях, вихованні підростаючого покоління (Огоновская И., Фукс А. та ін.).

Стаття презентує результати комплексного аналізу чорноморської проблематики в радянській історіографіi. Післявоєнні трансформачіі пануючого радянського історіографічного канону в напрямку тези про дружбу народів та посилення ролі руського народу в історичному розвитку призвели до змін в інтерпретації чорноморського регіону. Автори підручників акцентували увагу на спільних діях украйнського та російського народів у «поверненні» або «звільнені» південних степів від сусідів. Спільними рисами радянських підручників є одностайне виділення географічних меж регіону та підтримка козаџької колонізачії степів. Більша частина авторів підручників поділяла тезу про надзвичайну важливість чорноморського регіону для розвитку торгівлі та захисту кордонів.

Висновки. Комплексний аналіз радянських шкільних підручників з історії дозволив виокремити характерні риси образу чорноморського регіону та зробити висновок про маргінальне становище чорноморського регіону в радянській історіографії.

Ключові слова: Південна Україна, икільний підручник, Північне Причорномор'я, степ, козачутво.

CKazankov R., Ivanov S., 2020 
Вісник Харківського національного університету імені В. Н. Каразіна, 2020

Цель. Исследовать процесс формирования $u$ характерные черты образа черноморского региона в советских школьных учебниках по истории.

Методы. Основным исследовательским методом является контент-анализ советских школьных учебников по истории (для начальной и средней школь).

Результаты. В контексте частичных изменений базовых положений советской историографии в послевоенный период и становления новой наднациональной сообщности советского народа, важное значение приобретало исследование полиэтничных регионов, где происходило взаимодействие представителей этнических сообществ Советского Союза. $B$ данном контексте актуализировалось осмысление/переосмысление черноморской проблематики. Комплексный анализ советских икольных учебников по истории позволит сформировать представление о подходах в интерпретации черноморского региона.

Советские школьные учебники по истории изучались в большом количестве научных исследований. Однако черноморская проблематика до сих пор остается недостаточно исследованной. Опираясь на содержание советских учебников, авторы раскрывали самые разнообразные аспекты - проблематику исторической памяти, важные события (войны, револючии), формирование идентичности (KlymenkoL., Janmaat J., Gaworek N. u дp.). Отдельные аспекты, касаюшиеся черноморской проблематики, содержатся в научных работах, посвященных прочессу создания советских учебников (Телегуз И.), изучению влияния учебников на исторические и историографические исследования, воспитания подрастающего поколения (Огоновская И., Фукс А. и др.).

Данная статья отражает результаты комплексного исследования черноморской проблематики в советской историографии. Послевоенные трансформачии официального советского историографического канона в сторону тезиса «дружбы народов» и усиления роли русского народа в историческом развитии привели к изменениям в интерпетации черноморского региона. Авторы учебников акиентировали внимание на совместных действиях украинского и русского народов в «возвращении» или «освобождении»южных степей от враждебных соседей. Общими чертами советских учебников являются единогласное выделение территориальных границ региона и поддержка казацкой колонизации степей. Большая часть авторов учебников придержсивалась тезиса о чрезвычайной важности черноморского региона для развития торговли и защиты границ.

Выводы. Комплексный анализ советских школьных учебников по истории позволил выделить характерные черть образа черноморского региона и сделать вывод о маргинальном положении региона в советской историографии.

Ключевые слова: Южная Украина, школьный учебник, Северное Причерноморье, степь, казачество.

Purpose. The primary goal of the paper is to disclose the process of formation and to outline the essential features of the Black Sea region within the Soviet school history textbooks.

Methods. The Soviet school history textbooks' content analysis has been put as a primary research tool to achieve the paper's aims. Textbooks for primary and secondary school have been analyzed.

Results. The postwar period has been characterized by the partial modifications of the Soviet historiography and the forming of new supranational entity - "Soviet people". In this context the multiethnic region with the interaction between different ethnic entities' representatives had became the research agenda. This led to increasing significance of conceptualization/reconceptualization of the Black Sea region. The complex study of the Soviet school history textbooks would allow forming the representation of the prevailing approaches toward the Black Sea region.

Soviet school history textbooks' content has already been investigated in a whole bulk of papers. However, the Black Sea region's interpretation is still being vacant. Scholars try to disclose different issues using the textbooks' content such as historical memory, crucial events (wars, revolutions), forming the national identity and the like (Klymenko L., Janmaat J., Gaworek N., etc). A few relevant patterns can be found within the papers generalizing the process of Soviet textbooks 
Серія «Історія України. Українознавство: історичні та філософські науки», Вип. 30

creating (Teleguz I.), outlining the textbooks' significance for historical study, bringing up the new generations (Fuks A., Ogonovskaya I., etc).

The paper presents the results of complex research of the Black Sea region issues within the Soviet historiography. The postwar shift in official historiography canon toward the people's friendship and strengthening the Russians' influence in historical development has led to modifications of the Black Sea region's image. Textbook authors have put the stress to the common efforts of Ukrainian and Russian population in the "winning back" or "liberation" of the southern steppes from the hostile neighbors. Unanimously accepted the region's territorial limits and endorsement of Cossacks colonization of the steppes are the main shared features of the Soviet history textbooks. The colossal significance for the trade development and border protection issues has been accentuated by the vast majority of textbook authors.

Conclusions. The complex study of Soviet school history textbooks has made it feasible to circumscribe the essential features of the region's image and to conclude the marginality of the Black Sea region within the Soviet historiography.

Key words: Southern Ukraine, school textbook, the Northern Black Sea coast, steppes, Cossacks.

School textbooks have become important historical and historiographical sources as long as have contained the purified extraction of prevailing trends in understanding the past. Content analysis of Soviet history textbooks has already been put as a research goal for exploring different agendas (identity-making, specific historical events etc.) $[23 ; 30 ; 31 ; 33 ; 34]$ or as a part of generalization of the soviet education system's features $[20 ; 25 ; 26 ; 29 ; 32]$. However, the bulk of research up to now has been omitting the issue of the Black Sea region's image and distinguishing its core and subsequent elements within the Soviet history textbooks. By using the definition "the Black Sea region" author keeps in mind the only territory within the borders of Ukrainian state. The greater Black Sea region which involves parts of several adjacent countries around the Black Sea needs a distinct paper and stays out of the paper's scope.

The purpose of this paper is to shed light on the process of defining the Soviet version of the Black Sea region's image in the postwar period. The set of Soviet history textbooks for primary and secondary education (from 3 to 10 grades) have been revised. In some cases, we use several editions of one particular textbook. It has been chosen on purpose to trace feasible changes of the prevailing Black Sea region's official discourse.

In the Soviet society textbooks were the main tool in bringing up the new generations. That's why it was of great importance for the state. Soviet authorities gave a lot of attention to create a set of textbook appropriate for the Soviet schools [20, p. 269]. The long and difficult process of establishing the appropriate history textbook for the school system in the middle of the 1930s could be drowned as striking example. One of the most numerous history textbook for primary school from the middle of the 1930s untill the beginning of the 1950s edited by Professor A. V. Shestakov "Kratkiy kurs istorii SSSR" (Short outline of the history of the USSR) had been personally revised by J. Stalin who listed lots of personal "wishes" [20, p. 269]. All the changes were implemented and the textbook became the main instrument in young generations' education. In 1936 the Soviet government announced a competition for the best school textbook. Thought-provoking thing was that even A. V. Shestakov's book was awarded only the second prize [20, p. 269]. No one had been awarded the first prize! Secondary education was also provided with a set of textbooks. "Istoriya SSSR" (History of the USSR) edited by Professor A. Pankratova for 8, 9 and 10 grades with several editions was the most popular.

Within the "lesser evil" discourse which had been installing from the middle of the 1930s [15, p. 254] the region's interpretation became more outlined. The primary feature was the issue of protection of the state's borders from the neighbours who threatened the inner territories. One of the commonly used reasons was to guard people and lands in order to maintain further development. The end of the XVIII century was treated as a conquering the Black Sea shores by the Russian Empire in favour of local nobility and merchants $[16,10]$. A. V. Shestakov's textbook "History of 
Вісник Харківського національного університету імені В. Н. Каразіна, 2020

the USSR" for 3 and 4 grades treated the Russian state as "empire of landowners and merchants" $[16$, p. 60] were the driving forces in getting to the Black Sea shores.

In contrast to the above-mentioned paragraph, however, no evidence of the great interest of Soviet historiography toward the Black Sea region was detected. Moreover, the only beginning of the 1940s could be marked by the close steps in shedding light to the steppe region. Honour should be given to prominent Ukrainian historian N. Polonska-Vasylenko who earned her doctorate degree in 1940. Her thesis had set the basis for the region's image. To put is straight N. PolonskaVasylenko's interpretation included strategic relevance for the Russian state and twofold attitude toward Ukrainian Cossacks (border protectors and obstacle on the way of the trade development). The core features of N. Polonska-Vasylenko's perception would be later adjusted to the new vision of the historical past in the postwar period.

The postwar period in the Soviet historiography had been characterized by the process of significant changes. The abandonment of "Russian chauvinism" and interpretation of the Russian Empire as "a jail of people" was replaced by the strengthening the "people's friendship" thesis. Later it was supplemented with the highlighting the unique place of Russians among other nations within the Empire and later - the Soviet Union. In the middle of the 1950s final version of a renovated perception of the historical past was created [27, p. 28]. The first representation of the new version of the historical past was made by the several Decrees of the Soviet authorities in 1953. The 1954 "Thesis on the 300 Anniversary of the Reunification of Ukraine with Russia (16541954)" (later - "Thesis...") represented the complete version [34, p. 58]. "Thesis..." gave the authors the guideline to the historical process and accentuated the main issues and definitions.

The essential feature of the interpretation of the Black Sea region in post-war Soviet history textbooks was the profound attachment to the "Thesis...". The relevant party document contained one paragraph exclusively for the Black Sea region. It should be emphasized that some textbooks' authors while describing the region on a particular period used almost verbatim the relevant party document's statements [22, p. 11-12; 2, p. 207; 5, p. 91]. The key aspects of the interpretation of the Black Sea region consist of some essential components: the strategic value of the region, the attractiveness of these lands for the agricultural development, trade and obtaining significant profits, the idea of "liberating" or "winning back" the Black Sea region had been lost at a certain stage of development, and the most common thesis about the brotherhood and commonality of the Ukrainian and Russian peoples in the struggle for the Black Sea lands [22, p. 11-12].

The vast majority of textbooks in the history of the Ukrainian SSR have a specific substantial factor. There is unanimity of textbook authors' in defining the spatial boundaries of the region. The region was localized within the territory of three guberniyas of the Russian Empire - Kherson, Taurida and Ekaterinoslav [14, p. 172]. "Southern Ukraine" was comparatively typical definition for above-mentioned lands in the 1960-1980s textbooks. Meanwhile, the textbook authors in a general history of the USSR (M. Nechkina, T. Golubeva, P. Labengrub) prefer to use more neutral definitions. "The Black Sea coast" and "Southern steppes" were among the frequently used ones [3, p. 70-72]. The commonly used in the XIX century title "Novorossiya" (or New Russia) appeared periodically in the course of region's history [21, p. 222].

The key point of the region's interpretation in 1950-1980s textbooks is the return of primordial Russian territories. All that terrain was lost in favour of aggressive neighbors (Poland, Turkey) at a particular point of time. The interpretation of the Grand Duchy of Lithuania which incorporated a huge amount of Ukrainian lands in the XIV century was more controversial. On the one hand, Lithuanian feudal lords were condemned for the severe attitude towards Ukrainian (and Belorussian) peasants. On the other hand, the authors confessed an admiration by the well-known principality's particularities (language, law system) [7, p. 66].

The state's weakness was the main reason why the region was taken by the nomadic people. The main detrimental outcomes were the cutting off from the convenient Black Sea and significant deterioration of the trade's development. The long-way struggle to take it back finally ended at the end of the XVIII century. The relevant thesis can be easily justified by the chapters' titles such as "Liberation of the Southern Ukraine" [4, p. 87]. 
Серія «Історія України. Українознавство: історичні та філософські науки», Вип. 30

The southward movement of the Russian state and taking the Black Sea region were divided into two main stages. Firstly, the reign of Peter the Great was perceived as the first attempt to find a way to the sea. The second stage was associated with Catherine the Great and her active steps in enlarging the Russian Empire's borders. The vast majority of authors had pointed out several driving forces which imposed the urgent need to take the Black Sea lands: nobility and merchants. Both groups had distinct aspirations in taking new lands. Nobility urgently wanted to increase estates, so the steppe region was perceived as the terrain of new fertile soil [12, p. 243; 21, p. 215]. Merchants treated the southward movement as the best way of trade stimulation, searching new trade routes, increasing external ties with Europe and the Middle East, enlarging sales markets [7, p. 174-175].

The interpretation of the Black Sea region could be hardly imagined without the issue of Ukrainian Cossacks and its contribution to the region's history. Soviet history textbooks had disclosed this pattern in a very specific way. To start, the bulk of authors admitted the considerable contribution of Cossack entity to Ukrainian lands defense from hostile neighbours (chiefly Crimean Khanate, less - the Ottoman Empire) [18, p. 97; 5, p. 91]. Moreover, theirs attempts to colonize the Black Sea steppes also have found the authors' endorsement. On the other hand, perceiving the role of Ukrainian Cossacks was fulfilled with some ideological patterns. The prism of brotherhood and Ukrainian-Russian common historical development must have been the background according to the "Thesis..." [22, p. 11]. Due to the party guideline, the struggle of Ukrainian Cossacks against Tatars and Turks could have been successful only with the help of huge and strong Russian army [6, p. 45].

"Winning back" of the Black Sea region had been treated only in positive context. The stand of the Russian state on the Black Sea shores had been interpreted as the overcoming of the obstacles to the lands development and significant impact for the trade promotion both internal and external. The crushing of the Crimean Khanate and its frequent raids was among the considerable changes for Ukrainian lands and people. Moreover, the liberation of the steppes stipulated the growth of cities which became the economical, cultural centers (such as Odesa, Kherson).

The further Black Sea region's interpretation has several main features. Firstly, likewise the Western Ukraine or Galicia in particular, the Black Sea region was on the margins. Moreover, textbooks authors unconsciously neglected the region in the next stages of Russian state's development. It appeared only a few times in the XIX-XX century's history of Ukrainian territories and had been connected with significant events due to the Soviet vision of history.

Second half of the XIX century played an extremely valuable role in the Russian Empire's history - modernization processes, industry promotion, changes in the social structure. Meanwhile, all those events were only background for the emergence and increasing of labor movement for the textbooks' authors. It is well-known that Ukrainian lands were important part of the Russian Empire in the second half of the XIX century. The primary reason for that were natural resources (coal mining, wheat), industrial potential, railroads, ports and the like. The strong perception of the Black Sea region as a unique place where serfdom did not gain full strength likewise in the other Ukrainian regions was rather typical. Uniqueness, thus, led to much wider possibilities in the region's development [21, p. 222]. One of them was the creation of labor markets and increasing amount of workers (especially in Odesa) that attracted people from other Ukrainian and not only Ukrainian territories to the South [6, p.83].

The very few issues about the Black Sea region in the XX century were addressed by the authors. Likewise in the previous periods region appeared throughout crucial moments, e.g. 19171920 Revolution or World War II. In addition, authors prefer not to deal with the details and, actually, region "disappear" within the general trends of presenting the past. For instance, the interpretation of the Black Sea region throughout the 1941-1945 war can be called controversial. To start, textbooks authors highlighted some events which best match with the Soviet war myth. First of all, there are sieges of Odesa and Sevastopol treated as a "heroic chronicle of the Great Patriotic War" [13, p. 363]. However, neither page contains precise information about the 1944 events: regions liberation or Crimean Tatars deportation [13, p. 383]. The latter could be as one of the 
persuasive explanations why Soviet authors prefer not to depict the Black Sea region's issues within theirs textbooks. The deportation was not as an integrative part of Soviet war myth. Moreover, we can presume that the Black Sea region regarding its diverse ethnical composition was not properly ranked among the other Soviet regions.

The Black Sea region's image does not include the issue of the Crimea which is commonly treated as an essential part of the region. Textbooks' authors prefer not to mention the changes in the peninsula's status within the state. 1954 Crimea transfer to Ukrainian Socialist Republic was not introduced into the textbooks.

Summing up, it is necessary to note rather weak attention given to the problems of the Black Sea region. It is considerably inferior to the research interest in other Ukrainian regions (Left Bank, Right Bank, Slobozhanshchyna). The only Ukrainian regions which attracted less research attention were Bukovina and Zakarpattia. They were mentioned a few times: for instance, to underline the class struggle at the end of the XV century in Bukovina. Another example is the incorporation of the Zakarpattia within the borders of Ukrainian Soviet Socialist Republic in June 1945 after signing the treaty with the Czechoslovakia.

The authors' focus on the Dnieper Ukraine or Sloboda Ukraine leads to marginalization of the Black Sea region. This attitude is similar to that prescribed in the prewar school textbooks. Nevertheless, a number of differences could be found. Textbook authors of the second half of the $1930 \mathrm{~s}$ - at the beginning of the 1950s were concerned with the criticizing the southward movement under the pressure of distinct social groups (nobles, merchants). The postwar authors have been trying to adjust the region's history to the "friendship" between Russians and Ukrainians. This led to the disregarding the huge amount of essential features in the region's history and present. Textbooks authors tried to neglect some ethnic groups within the region's borders. The priority was given to the high ranking ethnic groups - Russians, "the second among the equals" - Ukrainians. However, other ethnic groups (Greeks, Bulgarians, Jews) have been staying less favorable for the authors due to the particularities of Soviet internal and ethnic policy.

The primary feature in the region's interpretation was the highlighting of its strategic benefits for the state's needs (trade, defense, international communication). However, the ambiguity in the region's perception has been evident. The borderland status had brought either negative or positive consequences. The people's distraction from the ordinary life by the frequent raids was labeled as a negative impact for the region. On the other hand, borderland region had its decisive gains. The southward movement has been perceived as a process stimulating further development either cultural or economic and only in positive tones. Notwithstanding, textbooks did not provide the idea that the Black Sea region's incorporation had finished the creation of Ukrainian national space which was present in some academic papers.

\section{Література}

1. Алексеев С. П., Карцов В. Г. История СССР. Учебная книга для 4 кл. Москва, 1961. 160 с. 2. Бущик Л. П. Історія СРСР. Ч.1. Вид. 4. За ред. акад. Г. М. Панкратової. Київ: Радянська школа, 1961. $232 \mathrm{c.}$

3. Голубєва Т. С. Оповідання з історії СРСР. 4 кл. Навчальна книга. Київ: Радянська школа. $1971.224 \mathrm{c}$.

4. Дядиченко В., Лось Ф. Історія Української РСР. Підручник для 7-8 класів. Вид. 11. Київ: Радянська школа, 1977. $151 \mathrm{c.}$

5. Дядиченко В., Лось Ф. Історія Української РСР. Підручник для 7-8 кл. Вид. 5-е. Київ: Радянська школа, 1971. 152 с.

6. Дядиченко В., Лось Ф., Спицкий В. История Украинской ССР. Учебник для 7-8 кл. Под ред. Ф. Лося. Киев: Радянська школа, 1973. 228 с.

7. Епифанов П. П., Федосов А. И. История СССР. Учебное пособие для 9-10 классов средней школы. Изд. 2-е. Москва: Просвещение, 1964. 434 с. 
Серія «Історія України. Українознавство: історичні та філософські науки», Вип. 30

8. Історія СРСР. Ч.1. Підручник для 7 класу середньої школи. Під ред. Г М. Панкратової. Вид. 7-е. Київ: Радянська школа. 232 с.

9. История СССР. Учебник для 10 кл. средней школы. Под ред. проф. А. М. Панкратовой. Изд. 11-е. Москва, 1952. 420 с.

10. История СССР. Учебник для 8 кл. средней школы. Под ред. проф. А. М. Панкратовой. Изд. 12-е. Москва, 1953. 245 с.

11. История СССР. Учебник для 9 кл. средней школы. Под ред. проф. А. М. Панкратовой. Изд. 12-е. Москва, 1953. 340 с.

12. История СССР. Учебник для 7 кл. Под ред. Б. А. Рыбакова. Москва: Просвещение, 1987. $287 \mathrm{c}$.

13. Касименко А. К. История Украинской ССР. Популярный очерк. Киев: Наукова думка. 1965. $480 \mathrm{c}$.

14. Книга для читання з історії Української РСР (7-8 кл.). За ред. Г. Я. Сергієнка. Київ: Радянська школа, 1988. 208 с.

15. Кравченко В. Переяславський комплекс в українській історіографії. Кравченко В. Україна, Імперія, Россія: Вибрані статті з модерної історії та історіографії. - К.: Критика, 2011. - С. $197-277$.

16. Краткий курс истории СССР. Учебник для 3 и 4 класса. Под ред. проф. А. В. Шестакова. Москва: Государственное учебно-педагогическое издательство, 1937. 225 с.

17. Мінц І. І., Карев Д. С. Історія СРСР. 3 відомостями з Констигуції СРСР, нової та новітньої історії зарубіжних крайн. Ч.2. Посібник для 8 кл. Київ: Радянська школа, 1962.344 с.

18. Нечкина М. В., Фадеев А. В. История СССР Учебное пособие для 7-го класса. Издание 5-е. Москва: Издательство «Просвещение», 1965. 265 с.

19. Нечкіна М. В., Лейбенгруб П. С. Історія СРСР. Підручник для 7 кл. Вид. 2-е. Київ: Радянська школа, 1982. 257c.

20. Огоновская И. С. Школьный учебник отечественной истории. Учебные издания как исторический источник. Документ. Архив. История. Современность. Bып. 12. Екатеринбург: Изд-во Урал. ун-та, 2011. С. 264-286.

21. Сахаров А. М., Краснобаев Б. И. История СССР. Пробный учебник для 7 кл. вечерней школы. Москва: Просвещение, 1968. 247 с.

22. Тезисы о 300-летии воссоединения Украины с Россией (1654 - 1954). Москва: Госполитиздат, 1954. 29 с.

23. Телегуз І. О. Особливості створення шкільних підручників в Радянській Україні у 1921 - 1934 рр. Наукові записки Кіровоградського державного педагогічного університету імені Володимира Винниченка. Серія: Історичні науки. 2012. Вип. 15. С. 127-134.

24. Федосов И. А. История СССР. Учебник 8 кл. Москва: Просвещение, 1982. 240 с.

25. Фукс А. Н. Формирование советской моноконцепции отечественной истории и ее отражение в школьном учебнике А. В. Шестакова (Краткий курс истории СССР). Вестник Московского государственного университета. Серия Исторические и политические науки. 2009. №2. C. 104-113.

26. Фукс А. Н. Значение школьных учебников отечественной истории для идеологического обеспечения национальной безопасности. Вестник МГОУ. Серия: История и политические науки. 2015. №1. С. 21 -32.

27. Яремчук В. Минуле України в історичній науці УРСР післясталінської доби. Острог: Видво Національного університету “Острозька академія”, 2009. 526 с.

28. Contemporary History Textbooks in the South Caucasus. Edited by L. Veselý. Prague, 2008. 90p.

29. Gaworek N. H. Education, Ideology, and Politics: History in Soviet Primary and Secondary Schools. The History Teacher. Vol. 11, No. 1 (Nov., 1977). pp. 55-74.

30. Janmaat J. Identity Construction and Education: The History of Ukraine in Soviet and PostSoviet Schoolbooks in Dilemmas of State-Led Nation Building in Ukraine. Edited by T. Kuzio and P. D'Anieri. Conecticut, Praeger, 2002. pp. $171-191$. 
31. Klymenko, L. (2013), Making Sense of World War II: How Russian and Ukrainian Textbooks Foster National Identities, CEURUS EU-Russia Papers, No. 7. pp. 1-20.

32. Rogger H. Politics, Ideology and History in the USSR: The Search for Coexistence. Soviet Studies, Vol. 16, No. 3, 1965. pp. 253-275.

33. Silova I., Michael M. Yaqub, G. Palandjian, Pedagogies of Space: (Re)Mapping National Territories, Borders, and Identities in Post-Soviet Textbooks in (Re)Constructing Memory: School Textbooks And Imagination of the Nation. Edited by J. H. Williams. Rotterdam. Sense Publishers, 2014. pp. 103-131. https://doi.org/10.2304/gsch.2014.4.3.195

34. Velychenko S. Shaping identity in Eastern Europe and Russia: Soviet-Russian and Polish accounts of Ukrainian history, 1914-1991. - New York: St. Martin's Press, 1993. 266 p.

\section{References}

1. Alekseev S. P., Kartsov V. G. Istoriya SSSR. Uchebnaya kniga dlya 4 kl [History of the SSSR. Teaching book for $4^{\text {th }}$ grade] (in Russian). Moskva, 1961. $160 \mathrm{~s}$.

2. Bushchyk L. P. Istoriia SRSR. Ch.1. Vyd. [History of the SSSR] (in Russian). 4. Za red. akad. H. M. Pankratovoi. Kyiv: Radianska shkola, 1961.232 s.

3. Holubieva T. S. Opovidannia z istorii SRSR. 4 kl. Navchalna knyha [History of the SSSR stories. Teaching book for $4^{\text {th }}$ grade] (in Ukrainian). K.: Radianska shkola. 1971. $224 \mathrm{~s}$.

4. Diadychenko V., Los F. Istoriia Ukrainskoi RSR. Pidruchnyk dlia 7-8 klasiv. [History of Ukrainian SSR. Textbook for 7-8 ${ }^{\text {th }}$ grade] (in Ukrainian). Vyd. 11. Kyiv: Radianska shkola, 1977. $151 \mathrm{~s}$.

5. Diadychenko V., Los F. Istoriia Ukrainskoi RSR. Pidruchnyk dlia 7-8 kl. [History of Ukrainian SSR. Textbook for 7-8 ${ }^{\text {th }}$ grade] (in Ukrainian). Vyd. 5-e. Kyiv: Radianska shkola, 1971. $152 \mathrm{~s}$.

6. Dyadichenko V., Los F., Spitskiy V. Istoriya Ukrainskoy SSR. Uchebnik dlya 7-8 kl. [History of Ukrainian SSR. Textbook for 7-8 ${ }^{\text {th }}$ grade] (in Ukrainian). Pod red. F. Losya. Kiev: Radyanska shkola. 1973. $228 \mathrm{~s}$.

7. Epifanov P. P., Fedosov A. I. Istoriya SSSR. Uchebnoe posobie dlya 9-10 klassov sredney shkolyi [History of the USSR. Teaching manual for $9-10^{\text {th }}$ grades of the secondary school] (in Russian). Izd. 2-e. Moskva: Prosveschenie, 1964. 434 s.

8. Istoriia SRSR. Ch.1. Pidruchnyk dlia 7 klasu serednoi shkoly [History of the USSR. Textbook for $7^{\text {th }}$ grade of the secondary school] (in Ukrainian). Pid red. H. M. Pankratovoi. Vyd. 7-e. K.: Radianska shkola. $232 \mathrm{~s}$.

9. Istoriya SSSR. Uchebnik dlya $10 \mathrm{kl}$. sredney shkolyi. [History of the USSR. Textbook for $10^{\text {th }}$ grade of the secondary school] (in Russian). Pod red. prof. A. M. Pankratovoy. Izd. 11-e. Moskva., 1952. 420 s.

10. Istoriya SSSR. Uchebnik dlya $8 \mathrm{kl}$. sredney shkolyi. [History of the USSR. Textbook for $8^{\text {th }}$ grade of the secondary school] (in Russian). Pod red. prof. A. M. Pankratovoy. Izd. 12-e. Moskva., 1953. 245 s.

11. Istoriya SSSR. Uchebnik dlya $9 \mathrm{kl}$. sredney shkolyi. [History of the USSR. Textbook for $9^{\text {th }}$ grade of the secondary school] (in Russian). Pod red. prof. A. M. Pankratovoy. Izd. 12-e. Moskva., 1953. 340 s.

12. Istoriya SSSR. Uchebnik dlya $7 \mathrm{kl}$. [History of the USSR. Textbook for the $7^{\text {th }}$ grade] (in Russian). Pod red. B. A. Ryibakova. Moskva: Prosveschenie, 1987. 287 s.

13. Kasimenko A. K. Istoriya Ukrainskoy SSR. Populyarnyiy ocherk [History of Ukrainian SSR. Popular outline] (in Ukrainian). Kiev: Naukova dumka. 1965. $480 \mathrm{~s}$.

14. Knyha dlia chytannia $\mathrm{z}$ istorii Ukrainskoi RSR (7-8 k1.) [Reading book in history of Ukrainian SSR] (in Ukrainian). Za red. H. Ya. Serhiienka. Kyiv: Radianska shkola, 1988. 208 s.

15. Kravchenko V. Pereiaslavskyi kompleks v ukrainskii istoriohrafii [Pereyaslav complex in Ukrainian Historiography] (in Ukrainian). Kravchenko V. Ukraina, Imperiia, Rosciia: Vybrani statti z modernoi istorii ta istoriohrafii. - K.: Krytyka, 2011. - S. 197-277.

16. Kratkiy kurs istorii SSSR. Uchebnik dlya 3 i 4 klassa. [History of the USSR short course. Textbook for $3-4^{\text {th }}$ grades] (in Russian). Pod red. prof. A. V. Shestakova. Moskva: Gosudarstvennoe uchebnopedagogicheskoe izdatelstvo, 1937.225 s. 
Серія «Історія України. Українознавство: історичні та філософські науки», Вип. 30

17. Mints I. I., Kariev D. S. Istoriia SRSR. Z vidomostiamy z Konstytutsii SRSR, novoi ta novitnoi istorii zarubizhnykh krain [History of the USSR with the excerpts from the USSR Constitution and Modern History of foreign countries] (in Ukrainian). Ch.2. Posibnyk dlia 8 kl. Kyiv: Radianska shkola, 1962. 344 s.

18. Nechkina M. V., Fadeev A. V. Istoriya SSSR. Uchebnoe posobie dlya 7-go klassa. [History of the USSR. Teaching manual for $7^{\text {th }}$ grade] (in Russian). Izdanie 5-e. Moskva: Izdatelstvo «Prosveschenie», 1965. $265 \mathrm{~s}$.

19. Nechkina M. V., Leibenhrub P. S. Istoriia SRSR. Pidruchnyk dlia $7 \mathrm{kl}$. [History of the USSR. Textbook for $7^{\text {th }}$ grade] (in Ukrainian). Vyd. 2-e. Kyiv: Radianska shkola, 1982. 257s.

20. Ogonovskaya I. S. Shkolnyiy uchebnik otechestvennoy istorii. Uchebnyie izdaniya kak istoricheskiy istochnik [School textbook in native history. Teaching publications as a historical source] (in Russian). Dokument. Arhiv. Istoriya. Sovremennost. Vyip. 12. Ekaterinburg: Izd-vo Ural. un-ta, 2011. S. 264-286.

21. Saharov A. M., Krasnobaev B. I. Istoriya SSSR. Probnyiy uchebnik dlya 7 kl. vecherney shkolyi [History of the USSR. Trial textbook for $7^{\text {th }}$ grade of the evening school] (in Russian). M.: Prosveschenie, 1968. $247 \mathrm{~s}$.

22. Tezisyi o 300-letii vossoedineniya Ukrainyi s Rossiey (1654 - 1954) [Tercentenary of Ukraine and Russia reunification Thesis (1654 - 1954)] (in Russian). Moskva: Gospolitizdat, 1954. $29 \mathrm{~s}$.

23. Telehuz I. O. Osoblyvosti stvorennia shkilnykh pidruchnykiv v Radianskii Ukraini u 1921 - 1934 rr. [School textbooks creation's particularities in Soviet Ukraine in 1921 - 1934] (in Ukrainian). Naukovi zapysky Kirovohradskoho derzhavnoho pedahohichnoho universytetu imeni Volodymyra Vynnychenka. Seriia: Istorychni nauky. 2012. Vyp. 15. S. 127-134.

24. Fedosov I. A. Istoriya SSSR. Uchebnik $8 \mathrm{kl}$. [History of the USSR. Textbook for $8^{\text {th }}$ grade] (in Russian). Moskva. Prosveschenie, 1982. 240 s.

25. Fuks A. N. Formirovanie sovetskoy monokontseptsii otechestvennoy istorii i ee otrazhenie v shkolnom uchebnike A. V. Shestakova (Kratkiy kurs istorii SSSR) [Creation of the Soviet monoconception of native history and its representation within the A. V. Shestkov's school textbook (Short course of History of the USSR)] (in Russian). Vestnik Moskovskogo gosudarstvennogo universiteta. Seriya Istoricheskie i politicheskie nauki. 2009. №2. S. 104-113.

26. Fuks A. N. Znachenie shkolnyih uchebnikov otechestvennoy istorii dlya ideologicheskogo obespecheniya natsionalnoy bezopasnosti [School textbooks' importance for the ideological ensuring of the national security] (in Russian). Vestnik MGOU. Seriya: Istoriya i politicheskie nauki. 2015. №1. S. 21 -32.

27. Iaremchuk V. Mynule Ukrainy v istorychnii nautsi URSR pislia-stalinskoi doby [Ukraine's past within the historical science of the Ukrainian SSR in the post-Stalin era] (in Ukrainian). Ostroh: Vyd-vo Natsionalnoho universytetu "Ostrozka akademiia", 2009. $526 \mathrm{~s}$.

28. Contemporary History Textbooks in the South Caucasus Edited by L. Veselý. Prague, 2008. 90 p.

29. Gaworek N. H. Education, Ideology, and Politics: History in Soviet Primary and Secondary Schools.

The History Teacher. Vol. 11, No. 1 (Nov., 1977). pp. 55-74.

30. Janmaat J. Identity Construction and Education: The History of Ukraine in Soviet and Post-Soviet Schoolbooks in Dilemmas of State-Led Nation Building in Ukraine. Edited by T. Kuzio and P. D'Anieri. Conecticut, Praeger, 2002. pp. $171-191$.

31. Klymenko, L. (2013), Making Sense of World War II: How Russian and Ukrainian Textbooks Foster National Identities, CEURUS EU-Russia Papers, No. 7. pp. 1-20.

32. Rogger H. Politics, Ideology and History in the USSR: The Search for Coexistence // Soviet Studies, Vol. 16, No. 3, 1965. pp. 253-275.

33. Silova I., Michael M. Yaqub, G. Palandjian, Pedagogies of Space: (Re)Mapping National Territories, Borders, and Identities in Post-Soviet Textbooks in (Re)Constructing Memory: School Textbooks And Imagination of the Nation. Edited by J. H. Williams. Rotterdam. Sense Publishers, 2014. pp. 103-131. https://doi.org/10.2304/gsch.2014.4.3.195

34. Velychenko S. Shaping identity in Eastern Europe and Russia: Soviet-Russian and Polish accounts of Ukrainian history, 1914-1991. - New York: St. Martin's Press, 1993.266 p. 